UDC $-579.69+577.112$

\title{
SPR investigations of the formation of intermediate layer of the immunosensor bioselective element based on the recombinant Staphylococcal protein $A$
}

\author{
A. E. Rachkov ${ }^{1}$, A. O. Bakhmachuk ${ }^{1,2}$, O. B. Gorbatiuk ${ }^{1}$, M. J. Matsishin ${ }^{1,3}$, \\ R. V. Khristosenko , Iu. V. Ushenin ${ }^{4}$, A. P. Soldatkin ${ }^{1,3}$ \\ ${ }^{1}$ Institute of Molecular Biology and Genetics, NAS of Ukraine, \\ 150, Akademika Zabolotnoho Str., Kyiv, Ukraine, 03680 \\ ${ }^{2}$ Educational and Scientific Center «Institute of Biology», \\ Taras Shevchenko National University of Kyiv, \\ 64/13, Volodymyrska Str., Kyiv, Ukraine, 01601 \\ ${ }^{3}$ Institute of High Technologies, Taras Shevchenko National University of Kyiv, \\ 2, korp.5, Pr. Akademika Hlushkova, Kyiv, Ukraine, 03022 \\ ${ }^{4}$ V. Ye. Lashkaryov Institute of Semiconductor Physics, NAS of Ukraine, \\ 41, Prospect Nauki, Kyiv, Ukraine, 03028 \\ oleksandr_rachkov@yahoo.com
}

\begin{abstract}
Aim. To investigate the formation of an intermediate layer of the immunosensor bioselective element based on the recombinant protein A from Staphylococcus aureus with cysteine residue (SPA-Cys) and its interactions with human IgG using the SPR spectrometer «Plasmon». Methods. The activity of the immune components applied was tested by ELISA. The spectrometry of surface plasmon resonance was used for studying protein immobilization on a gold sensor surface and interactions between the immobilized SPA-Cys and human immunoglobulin. Results. A direct dependence of the sensor response on the concentration of SPA-Cys in the range of 0.2 to $2 \mu \mathrm{M}$ at its immobilization was demonstrated. The efficiency of blocking nonspecific adsorption sites on the sensor surface with milk proteins and the direct dependence of the sensor response on IgG concentration and surface density of immobilized SPA-Cys were shown. Fitting the experimental data to a Langmuir plot yields a $K_{\mathrm{d}}$ value for SPA-Cys/IgG binding $8.5 \pm 0.7 \times 10^{-8} \mathrm{M}\left(K_{\mathrm{a}}=1.2 \pm 0.1 \times 10^{7} \mathrm{M}^{-1}\right)$. The determined equilibrium binding constant indicates a quite strong interaction and its value is consistent with the literature data. Conclusions. A successful immobilization of SPA-Cys on a gold surface of the SPR spectrometer while preserving its high immunoglobulin-binding activity, selectivity and stability of the sensor response confirms the efficiency of SPA-Cys as an intermediate component for the creation of the immunosensor bioselective elements.
\end{abstract}

Ke yw or d s: immunoglobulin, recombinant Staphylococcal protein A, surface plasmon resonance, protein immobilization, immunosensor, equilibrium binding constant.

\section{Introduction}

The development of approaches and tools of analytical biotechnology can help significantly to upgrade the quality of human life by improving the methods of biomedical diagnostics, molecular engineering, environmental monitoring, food analysis, drug discov- ery, etc. As compared with existing standard analytical approaches, the biosensor methods of analysis have a number of advantages: they provide easy, fast, accurate, highly sensitive, specific, and cheap procedure of the measurement. Besides, the real-time measurements are possible, while only a minimal probe pretreatment is necessary. A biosensor is a self-con-

(C) 2015 A. E. Rachkov et al.; Published by the Institute of Molecular Biology and Genetics, NAS of Ukraine on behalf of Biopolymers and Cell. This is an Open Access article distributed under the terms of the Creative Commons Attribution License (http://creativecommons.org/licenses/by/4.0/), which permits unrestricted reuse, distribution, and reproduction in any medium, provided the original work is properly cited 
tained device consisting of two functional parts. A bioselective element is in direct contact with a physical transducer, which transforms the information from biorecognition domain into an electrical or an optical signal [1].

The use of the variety of immune components is very attractive in this area of research. The immunosensors seem to be promising and helpful technique, offering a high specificity through the use of immune molecules, simple operation, uncomplicated sample preparation and high sensitivity [2]. The effective immobilization of either an antibody or an antigen on the sensing surface with preserving their functional activity is an important step in achieving a highly reliable immunosensor. This immobilization step affects the sensitivity and specificity of the sensor. However, during the immobilization of antibodies their antigen-binding activity is usually much lower in comparison with the same antibody activity in a free state due to the low density of the antigenbinding sites. The main reasons for this are believed to be a random orientation of antibodies on the sensor surface and a steric hindrance caused by the influence of the surface of a solid substrate.

Although physical adsorption does not require the use of several materials and complex reactions, it also leads to the serious drawbacks, such as the protein denaturation, very low stability and random orientation of the proteins. So they experience conformational changes that make their functional sites inactive or inaccessible, leading to the complicated interaction with the analyte $[3,4]$. The covalent immobilization by coupling IgG to a chemically activated matrix ensures much more reliable attachment to a sensor surface. However, this method has the disadvantage that is a heterogeneous immobilization and, therefore, some of the attachment sites interfere with the protein functional regions.

Regardless of physical adsorption or covalent binding, the immunoglobulin molecules are arranged on the substrate surface in a disordered manner, part of the active sites is covered due to the direct contact with the substrate, resulting in the loss of the recognition combining ability of the target molecule [5]. A specific orientation (or an oriented immobilization) is a promising alternative to physical adsorption or covalent binding. It can be accomplished by using an intermediate molecules directly attached to the sensor surface. One of the best candidates for the role of the intermediate molecule is immunoglobulin-binding Staphylococcal protein A (SPA). SPA selectively binds the Fc-domain of antibody leaving the Fabregion available to detect an antigen. The SPA molecule structure includes a signaling sequence [6], a IgG-binding region consisting of five highly homologous domains, and a C-terminal anchoring part, which attaches the protein to the bacterial cell wall $[7,8]$. SPA molecules are highly resistant to the denaturing factors: they are thermostable, resistant to a wide range of $\mathrm{pH}$ (1-12), and are not destroyed by trypsin cleavage [9]. The first use of SPA for the immunosensing applications was reported by Muramatsu et al. [10]. They designed a piezoelectric biosensor for the human IgG detection by SPA covalently immobilized via 3-aminopropyltriethoxysilane and glutaraldehyde. Prusak-Sochaczewski and Luong proposed an idea of using SPA as an intermediate protein for immobilization of the antibodies for the human serum albumin detection. In that case, SPA was physically adsorbed onto the gold electrodes under conditions close to the isoelectric point of the protein $\mathrm{A}$ (pH 5.5) [11].

However, even if the antibodies are not randomly connected to the surface coated with SPA, the protein A itself meets the same problem of the random immobilization [12]. An alternative method for immobilizing proteins is to use a genetic engineering approach, in which a specific attachment site is selectively introduced into a non-essential part of the recombinant protein. It was shown that a single cysteine residue introduced into the C-terminal part of the recombinant IgG-binding molecules can be used for their immobilization on a thiol-containing solid matrix [13]. It was also shown that the recombinant protein A with a specially introduced cysteine residue increases the reliability of protein immobilization via thiol adsorption on the gold sensor surface [12]. In our previous work [14] the original plasmid pET24-SPA-6HisCys was constructed, the recombinant protein A contained all five IgG-binding doma- 
ins, 6His-tag and C-terminal cysteine residue (SPACys) was obtained and its immobilization on a gold sensor surface was demonstrated.

The optical biosensors based on the surface plasmon resonance (SPR) allow direct registration in real time a wide range of intermolecular interactions without any labels [15]. Unlike the well-known, but extremely expensive bench-top SPR spectrometers «Biacore», SPR spectrometers «Plasmon» developed at V. Ye. Lashkaryov Institute of Semiconductor Physics of National Academy of Sciences of Ukraine are small, rather simple in operation, and much cheaper devices $[16,17]$. Therefore, the aim of this work was to investigate the formation of intermediate layer of the immunosensor bioselective element based on the recombinant protein A from Staphylococcus aureus with cysteine residue (SPA-Cys), and its interactions with human IgG using the SPR spectrometer «Plasmon».

\section{Methods and Materials}

$\mathrm{NaCl}, \mathrm{KH}_{2} \mathrm{PO}_{4}$, sodium citrate, $p$-nitrophenyl phosphate, Tween 20 and bovine serum albumin (BSA) were purchased from «Sigma» (USA), $\mathrm{Na}_{2} \mathrm{HPO}_{4}-$ from «Applichem» (Germany), skim milk powder from «Fluka» (Switzerland), $\mathrm{MgSO}_{4}$ - from «Arterium» (Ukraine).

Human IgG was purified by affinity chromatography as described in [14]. The genetically engineered fusion protein containing five IgG-binding domains of SPA and the bacterial alkaline phosphatase with enhanced catalytic properties (SPA-BAPmut) was obtained as described in [18].

\section{Synthesis and purification of SPA-Cys}

The recombinant Staphylococcal protein A with cysteine residue (SPA-Cys) was synthesized and purified as described earlier [14]. Briefly, the DNA sequences encoding the IgG-binding region of SPA, His-tag and cysteine were genetically fused and expressed in E. coli in the soluble form using a modified auto-induction protocol. The purification of the target protein was performed by immobilized-metal affinity chromatography in the native conditions. SPA-Cys was obtained in a functionally active state with purity $\sim 95 \%$.

\section{Competitive ELISA}

The wells of the immunological plate were coated overnight at $4{ }^{\circ} \mathrm{C}$ with $100 \mu \mathrm{L} 4 \mu \mathrm{g} / \mathrm{ml}$ IgG in carbonate buffer, $\mathrm{pH}$ 9, and then washed with PBS containing $0.1 \%$ Tween 20 (PBST). The surface of the wells was blocked to prevent nonspecific sorption with $150 \mu 12 \mathrm{mg} / \mathrm{ml}$ of skim milk powder solution in PBS. After 1 hour incubation at $37^{\circ} \mathrm{C}$ the plates were washed with PBST. The mixtures of $50 \mu \mathrm{l} 4 \mu \mathrm{g} / \mathrm{ml}$ fusion protein containing the IgG-binding domains of SPA and the bacterial alkaline phosphatase with enhanced catalytic properties (SPA-BAPmut) with $50 \mu \mathrm{l}$ PBS or with $50 \mu \mathrm{l}$ SPA-Cys solutions of different concentrations were added to the wells. After 1 hour incubation at $37^{\circ} \mathrm{C}$ the plates were washed with PBST and phosphatase buffer (0.1 M Tris- $\mathrm{HCl}, \mathrm{pH} 9.5$; $\left.0.14 \mathrm{M} \mathrm{NaCl}, 0.015 \mathrm{M} \mathrm{MgSO}_{4}\right)$, and $100 \mu \mathrm{l}$ of substrate solution ( $p$-nitrophenyl phosphate in phosphatase buffer) was added. After incubation for $30 \mathrm{~min}$ at room temperature, color development was stopped with $1 \mathrm{M}$ $\mathrm{NaOH}(50 \mu \mathrm{L}$ per well) and the absorbance was measured at $405 \mathrm{~nm}$ using the micro plate reader «Titertek Multiskan MCC/340» (Germany).

\section{SPR spectrometric analysis of protein-protein interactions}

The glass plates with a thin layer of gold were cleaned and mounted on the spectrometer prism as described in [19]. SPR analysis was performed by using a measuring flow-cell of the spectrometer «Plasmon- $4 \mathrm{~m}$ » and the peristaltic pump «Ismatec» (the pump speed of $\sim 40 \mu 1 / \mathrm{min}$ ). At first the measuring flow-cell was thoroughly washed by working buffer solution (PBS) to stabilize the SPR signal. Then a sample (usually $120 \mu \mathrm{l}$ ) was injected and incubated with the pump switched off for $30 \mathrm{~min}$ for the protein immobilization on the sensor surface, and for 10 min for the interactions of immobilized components with their molecules-partners. After that the measuring flow-cell was washed by PBS again until there was a stable SPR signal. To distinguish an actual sensor response caused by the interactions between a sample and the sensor surface or preliminary immobilized components from the signal caused by the 
random fluctuations of medium refractive index, it is necessary to wash the flow-cell before and after each sample by the same buffer solution, and only then to determine a value of the SPR response.

\section{SPA-Cys/IgG binding constant determination}

To analyze the binding SPA-Cys and human IgG the classic Langmuir model of heterogeneous binding was used. In general, the interactions between immobilized SPA-Cys and IgG is described by

$$
[S P A]+[\operatorname{Ig} G] \stackrel{K_{d}}{\longleftrightarrow}[A G]
$$

where $[S P A]$ is the number of available IgG-binding sites of the immobilized SPA-Cys, $[\operatorname{Ig} G]$ is immunoglobulin concentration in the solution, $[A G]$ is the number of complexes formed between the immobilized SPA-Cys and IgG. The process is characterized by equilibrium dissociation constant $K_{d}$. Langmuir equation of the curve that describes this process is written as follows:

$$
[A G]=\frac{[\operatorname{Ig} G] \cdot[A G]_{\max }}{K_{d}+[\operatorname{Ig} G]}
$$

Its linearized form, called the Skatchard equation, permits to get simply and clearly a value of the equilibrium constants and a value of the maximum number of SPA-Cys/IgG complexes:

$$
\frac{[A G]}{[\operatorname{Ig} G]}=-\frac{[A G]}{K_{d}}+\frac{[A G]_{\max }}{K_{d}}
$$

In order to obtain the characteristic parameters one can use the nonlinear least squares for the basic Langmuir equation or the least squares method for the Skatchard equation.

\section{Results and Discussion}

Before applying the immune components for the biosensor analysis, their activity was tested using the competitive format of ELISA. The SPA-Cys solutions of different concentrations and a fixed concentration of the fusion protein containing IgG-binding domains of SPA and the bacterial alkaline phosphatase with enhanced catalytic properties (SPA-BAPmut) were added to the immobilized human IgG. If SPA-
Cys actively binds to the immobilized IgG and competes with SPA-BAPmut, the results of ELISA will be in an inverse proportion to the concentration of SPA-Cys. The results shown in Fig. 1 confirmed our expectations: the absorbance values while adding SPA-Cys and SPA-BAPmut are significantly lower than the control values (only SPA-BAPmut) and are in the inverse proportion to the concentration of SPA-Cys. We can conclude that SPA-Cys interacts specifically with the immobilized IgG and demonstrates a sufficiently high activity.

In the previous work [14], a possibility of the successful immobilization of the recombinant SPACys on the gold sensor surface of SPR spectrometer «Plasmon-4m» was demonstrated after the injection of a sample of the purified SPA-Cys into the measuring flow-cell and its incubation there. In the present work, the dependence of the immobilization level on the concentration of SPA-Cys is investigated. A linear part of this dependence was observed in the range from 0 to $0.5 \mu \mathrm{M}$ SPA-Cys while $2 \mu \mathrm{M}$ SPA-Cys showed a close-to-saturation level of immobilization (Fig. 2).

According to the conversion factor of the SPR response into the value of surface density of the immobilized protein [20], this value when using $2 \mu \mathrm{M}$ SPA-Cys was $1.1 \pm 0.2 \mathrm{ng} / \mathrm{mm}^{2}$. Given the molecular weight of SPA-Cys (34.5 kDa), we can calculate that in average approximately $51 \mathrm{~nm}^{2}$ of the sensor surface falls on one molecule of the immobilized SPA-Cys. It means that a lot of free space (the potential sites for the nonspecific adsorption during the next stages of the sensor work) is left. In this regard, the need to block efficiently the nonspecific adsorption on these free sites becomes even more obvious.

An attempt to apply BSA as a blocking agent did not give a satisfactory result: the saturation of the sensor response was achieved after 3 consecutive injections of $0.2 \mathrm{mg} / \mathrm{ml} \mathrm{BSA}$ into the measuring flow-cell, and its growth $(\sim 0.08$ angular degrees) corresponds to $\sim 0.8 \mathrm{ng} / \mathrm{mm}^{2}$ only. Even taking into consideration a bigger size of BSA molecules, the average value 41 $\mathrm{nm}^{2}$ of the sensor surface per each immobilized protein molecules (SPA-Cys and BSA) indicates a quite large area of the free sensor surface. 
Unlike BSA, the first injection of $0.2 \mathrm{mg} / \mathrm{ml} \mathrm{skim}$ milk powder into the measuring flow-cell caused a very big sensor response. Washing the measuring cell by PBS led to a moderate signal reduction (reflecting a relatively small portion of weakly adsorbed milk proteins compared with strongly immobilized ones). Each following injections gave gradually decreasing increment of sensor response, and four consecutive injections of $0.2 \mathrm{mg} / \mathrm{ml}$ skim milk powder were necessary to approach to the saturation of the sensor response ( $\sim 0.35$ angular degrees). It corresponds to protein surface density $\sim 3.5 \pm 0.4 \mathrm{ng} / \mathrm{mm}^{2}$. In average, approximately $12 \mathrm{~nm}^{2}$ of the sensor surface falls on one molecule of the immobilized SPA-Cys and milk proteins. These values are in good agreement with parameters of the protein monolayer.

To check, whether the immobilized molecules of SPA-Cys retain their immunoglobulin-binding activity, human IgG was injected into the measuring flow-cell, the sensor surface which was previously treated by $1 \mu \mathrm{M}$ SPA-Cys and free sites of the chip were blocked by milk proteins. The sensogram 1 in Fig. 3 shows that three consecutive injections of 10,20 and $40 \mu \mathrm{g} / \mathrm{ml} \mathrm{IgG}$ cause a significant sensor response that assumes its active interactions with the immobilized SPA-Cys.

However, how much this result reflects the interactions only between IgG and the immobilized SPACys, and to what extent the nonspecific interactions with milk proteins or with bare portions of the gold surface are involved? To answer this question, the same IgG samples were injected into the measuring flow-cell, the sensor surface of which was treated by only milk proteins (without SPA-Cys). As seen in the sensogram 2 in Fig. 3 the IgG injections in the absence of SPA-Cys cause almost no sensor response. Thus, it is clear that IgG does interact with SPA-Cys, and does not with milk proteins. Furthermore, the sensogram 2 in Fig. 3 demonstrates a high efficiency of the applied blocking procedure. Otherwise, IgG (in the absence of the immobilized SPA-Cys) would cause a noticeable sensor response, as it could be adsorbed on the unblocked sites of the gold surface.

For a further use of the prepared bioselective element, an efficient regeneration procedure should be applied. In fact, to this end, researchers use various

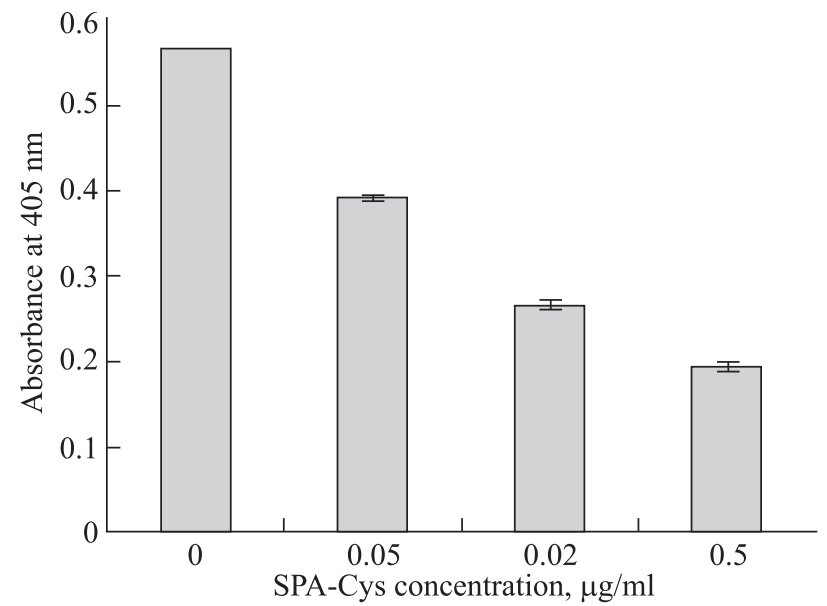

Fig. 1. The competitive ELISA for testing the IgG-binding activity of the purified SPA-Cys

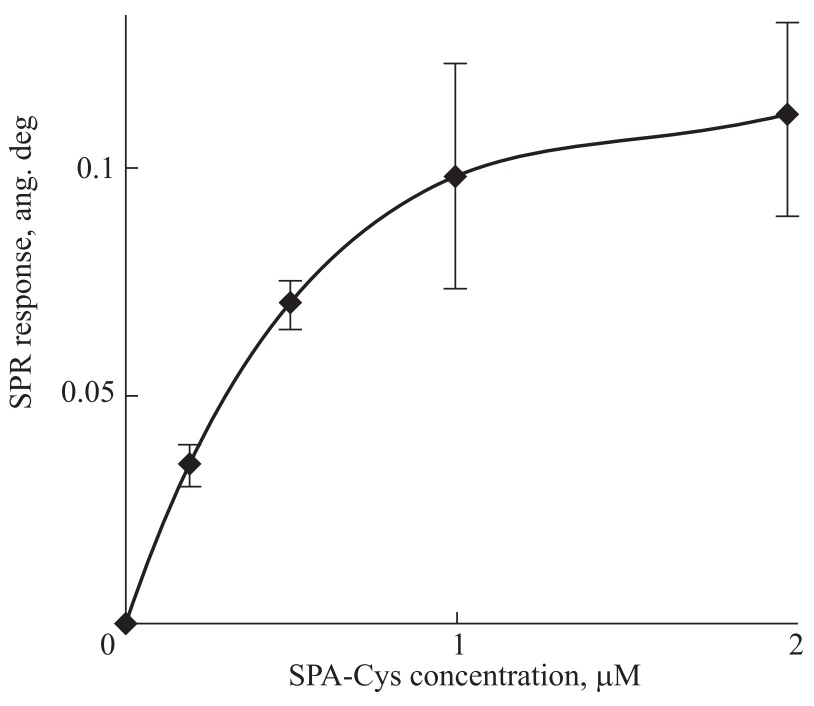

Fig. 2. The dependence of the sensor response (index of immobilization level) on the injected SPA-Cys concentration

solvents or reagents that change the $\mathrm{pH}$ and ionic strength of the solution, acting on a charge of interacting molecules and thus their tertiary structure [21]. In this case, after treating the sensor surface with a solution of $40 \mathrm{mM}$ sodium citrate buffer ( $\mathrm{pH}$ 2.5) [22] the level of sensor signals almost backs to the values that preceded the IgG injections (Fig. 3). It shows a quite effective disruption of the links between the immobilized SPA-Cys and IgG and the removal of the latter. The subsequent injections of new IgG samples showed that such regeneration procedure has not es- 


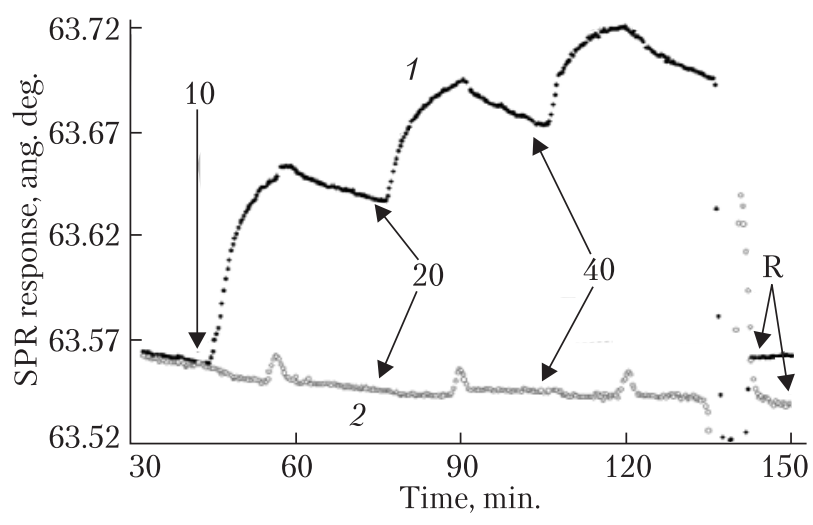

Fig. 3. SPR sensograms representing the interactions of $\operatorname{IgG}(10$, 20 and $40 \mu \mathrm{g} / \mathrm{ml}$ ) with the gold sensor surface of SPR spectrometer «Plasmon-4m» after immobilization of $1 \mu \mathrm{M}$ SPA-Cys and blocking by skim milk powder (1) or after blocking by only skim milk powder (2). R - SPR signals after the regeneration

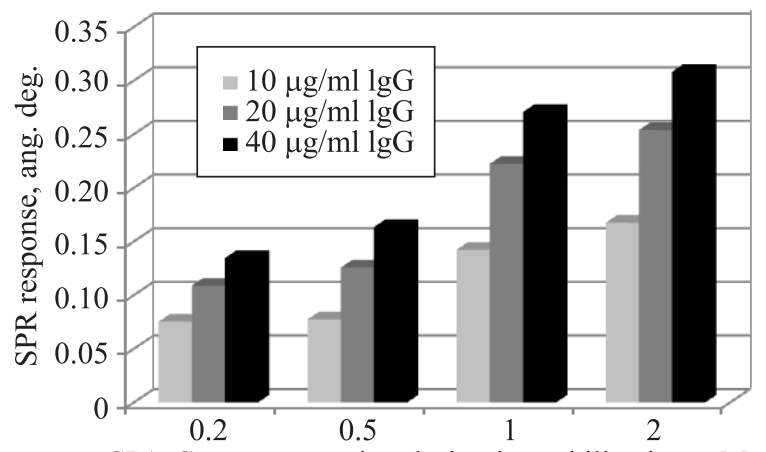

SPA-Cyr concentration during immobilization, $\mu \mathrm{M}$

Fig. 4. Histogram of the SPR sensor responses on consecutive injections of 10,20 and $40 \mu \mathrm{g} / \mathrm{ml}$ human IgG at their interactions with bioselective elements obtained at different SPA-Cys concentrations

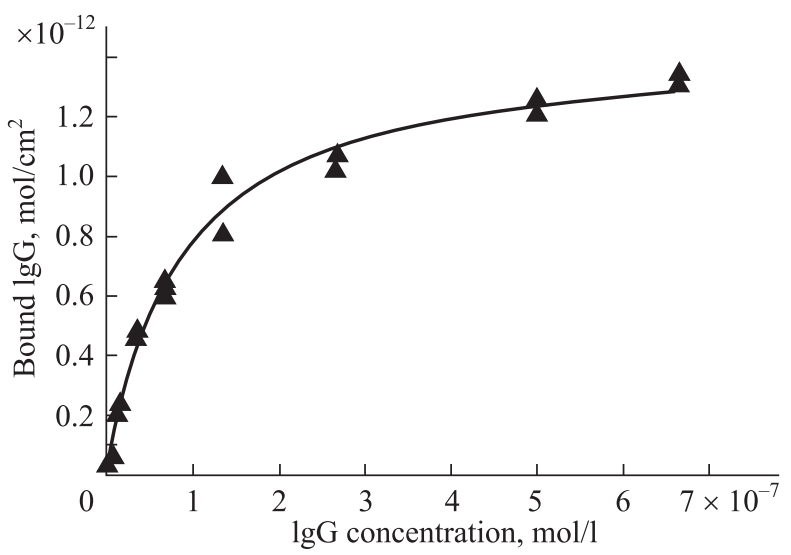

Fig. 5. Fitting the experimental data obtained for the human IgG binding to the immobilized SPA-Cys to Langmuir plot sentially affected the level of immunoglobulin-binding activity of the immobilized SPA-Cys. Thus, the re-use of the immunosensor bioselective element formed on the basis of SPA-Cys is possible.

Does a level of the immobilized SPA-Cys influence on a value of the sensor response at IgG injections? To answer this question we conducted the following experiment with four bioselective elements obtained at different SPA-Cys concentrations. As shown in Fig. 4 the values of the SPR response are directly dependent on the surface density of immobilized SPA-Cys and on the IgG concentration, at least in the range from 10 to $40 \mu \mathrm{g} / \mathrm{ml}$.

To investigate the effect of storage time of the immunosensor bioselective element, formed on the basis of SPA-Cys, on its properties, the IgG samples of the same concentration $(10 \mu \mathrm{g} / \mathrm{ml})$ were injected within some period of time into the measuring flow-cell, the sensor surface of which was previously treated by $1 \mu \mathrm{M}$ SPA-Cys and was blocked by milk proteins. A gradual decrease in the sensor response was observed, however, the first ten days the immunosensor bioselective element kept a relatively high immunoglobulin-binding activity. Note that this experiment was conducted at a rather high ambient temperature $\left(25-27{ }^{\circ} \mathrm{C}\right)$ without the use of any preservatives. So, there is some opportunity for improving the achieved level.

The injection of the IgG samples of various concentrations (from 0.5 to $100 \mu \mathrm{g} / \mathrm{ml}$ or from 3 to $670 \mathrm{nM}$ ) into the measuring flow-cell with the sensor previously treated by $1 \mu \mathrm{M}$ SPA-Cys (surface density $\sim 1 \mathrm{ng} / \mathrm{mm}^{2}$ ) allowed us to get the dependence of response on the IgG concentration. In turn, the data presented in the coordinates $\mathrm{mol} / \mathrm{cm}^{2}$ of the bound IgG vs. mol/1 of the free IgG (Fig. 5), using the Langmuir model yielded the values of equilibrium dissociation constant for IgG/SPA-Cys interaction $8.5 \pm 0.7 \times 10^{-8} \mathrm{M}\left(K_{a}=1.2 \pm 0.1 \times 10^{7} \mathrm{M}^{-1}\right)$ and the value $[A G]_{\max }=1.5 \pm 0.1 \times 10^{-12} \mathrm{~mol} / \mathrm{cm}^{2}$. The use of Skatchard plot provided very close data.

The equilibrium binding constant obtained for $\mathrm{IgG}$ binding to the immobilized SPA-Cys indicates their quite strong interaction and its value is consistent with the values for IgG binding to the immobilized SPA determined by others researchers $\left(K_{a}=1.8-4.8 \times 10^{7} \mathrm{M}^{-1}\right)$ [23-25]. 
In conclusions, when studying the process of immobilization of the recombinant protein A from Staphylococcus aureus with the C-terminal cysteine residue (SPA-Cys) on a gold surface of the SPR spectrometer the direct dependence on the concentration of SPA-Cys in the range from 0.2 to $2 \mu \mathrm{M}$ was revealed. The efficiency of blocking the nonspecific adsorption sites on the sensor surface with milk proteins and lack of $\mathrm{IgG}$ interaction with them as well as the direct dependence of the sensor response on the IgG concentration and surface density of the immobilized SPA-Cys were shown. The determined equilibrium binding constant for IgG binding to the immobilized SPA-Cys indicates their quite strong interaction and its value is consistent with the literature data.

The successful immobilization of SPA-Cys on a gold surface of the SPR spectrometer while preserving its high immunoglobulin-binding activity, selectivity and stability of the sensor response confirms the efficiency of SPA-Cys as intermediate component for the creation of the immunosensor bioselective elements.

The bioselective elements based on SPA-Cys can be used as a «universal platform» for the oriented immobilization of antibodies against almost unlimited variety of antigens, as well as for an express screening of immunological status e.g., when testing immunodeficiency.

\section{Funding}

This work was partially supported by STCU project N 6044; 2015.

\section{REFERENCES}

1. Soldatkin AP, Dzyadevych SV, Korpan YI, Sergeyeva TA, Arkhypova VN, Biloivan OA, Soldatkin OO, Shkotova LV, Zinchenko OA, Peshkova VM, Saiapina OY, Marchenko SV, El'skaya $A V$. Biosensors. A quarter of a century of R\&D experience. Biopolym Cell. 2013; 29(3):188-206.

2. Ramanaviciene A, German N, Kausaite-Minkstimiene A, Voronovic J, Kirlyte J, Ramanavicius A. Comparative study of surface plasmon resonance, electrochemical and electroassisted chemiluminescence methods based immunosensor for the determination of antibodies against human growth hormone. Biosens Bioelectron. 2012; 36(1):48-55.

3. de Juan-Franco E, Caruz A, Pedrajas J, Lechuga L. Sitedirected antibody immobilization using a protein A-gold binding domain fusion protein for enhanced SPR immunosensing. Analyst. 2013; 138(7):2023-31.
4. Makaraviciute A, Ramanaviciene A. Site-directed antibody immobilization techniques for immunosensors. Biosens Bioelectron. 2013; 50:460-71.

5. Wang $C$, Feng B. [Research progress on site-oriented and three-dimensional immobilization of proteins]. Mol Biol (Mosk). 2015;49(1):3-25.

6. Abrahmsen L, Moks T, Nilsson B, Hellman U, Uhlen M. Analysis of signals for secretion in the staphylococcal protein A gene. EMBO J. 1985; 4(13B):3901-6.

7. Moks T, Abrahmsen L, Nilsson B, Hellman U, Sjoquist J, Uhlen M. Staphylococcal protein A consists of five IgGbinding domains. Eur J Biochem. 1986; 156(3):637-43.

8. Sjodahl J. Repetitive sequences in protein A from Staphylococcus aureus. Eur J Biochem. 1977; 73(2):343-51.

9. Sidorin E, Solov'eva T. IgG-binding proteins of bacteria. Biochemistry (Moscow). 2011; 76(3):295-308.

10. Muramatsu H, Dicks J, Tamiya E, Karube I. Piezoelectric crystal biosensor modified with protein A for determination of immunoglobulins. Anal Chem. 1987; 59(23):2760-3.

11. Prusak-Sochaczewski E, Luong J. A new approach to the development of a reusable piezoelectric crystal biosensor. Anal Lett. 1990; 23(3):401-9.

12. Kanno S, Yanagida Y, Haruyama T, Kobatake E, Aizawa M. Assembling of engineered IgG-binding protein on gold surface for highly oriented antibody immobilization. J Biotechnol. 2000; 76(2-3):207-14.

13. Ljungquist C, Jansson B, Moks T, Uhlen M. Thiol-directed immobilization of recombinant IgG-binding receptors. Eur J Biochem. 1989; 186:557-61.

14. Gorbatiuk OB, Bakhmachuk AO, Dubey LV, Usenko MO, Irodov DM, Okunev OV, Kostenko OM, Rachkov AE, Kordium VA. Recombinant Staphylococcal protein A with cysteine residue for preparation of affinity chromatography stationary phase and immunosensor applications. Biopolym Cell. 2015; 31(2): 115-22.

15. Homola J. Surface plasmon resonance sensors for detection of chemical and biological species. Chem Rev. 2008; 108 (2):462-93.

16. Rengevich OV, Shirshov YuM, Ushenin YuV, Beketov AG. Separate determination of thickness and optical parameters by surface plasmon resonance: accuracy consideration. Semiconductor physics, quantum electronics and optoelectronics. 1999; 2(2):28-35.

17. Gridina N, Dorozinsky G, Khristosenko R, Maslov V, Samoylov A, Ushenin Yu, Shirshov Yu. Surface plasmon resonance biosensor. Sens Transduc J. 2013; 149(2): 60-8.

18. Gorbatiuk OB, Okunev OV, Nikolaev YuS, Svyatenko OV, Kordium VA. Construction, expression, functional characterization and practical application of fusion protein SPABAPmut. Biopolym Cell. 2013; 29(1):49-54.

19. Rachkov A, Holodova Yu, Ushenin Yu, Miroshnichenko D, Telegeev G, Soldatkin A. Development of bioselective element of SPR spectrometer for monitoring of oligonucleotide interactions and comparison with thermodynamic calculations. Sens Lett. 2009; 7(5):957-61. 
20. Stenberg E, Persson B, Roos H, Urbaniczky C. Quantitative determination of surface concentration of protein with surface plasmon resonance using radiolabeled proteins. $J$ Colloid Interface Sci. 1991;143(2):513-26.

21. Goode JA, Rushworth JV, Millner PA. Biosensor regeneration: a review of common techniques and outcomes. Langmuir. 2015; 31(23):6267-76.

22. Sergeyeva TA, Soldatkin AP, Rachkov AE, Tereschenko MI, Piletsky $S A$, El skaya AV. $\beta$-Lactamase label-based potentiometric biosensor for $\alpha-2$ interferon detection. Anal Chim Acta. 1999; 390(1-3):73-81.

23. Schwartz MP, Alvarez SD, Sailor MJ. A porous $\mathrm{SiO}_{2}$ interferometric biosensor for quantitative determination of protein interactions: binding of protein A to immunoglobulins derived from different species. Anal Chem. 2007;79(1):327-34.

24. Lindmark R, Biriell C, Sjoquist J. Quantitation of specific IgG antibodies in rabbits by a solid-phase radioimmunoassay with 125I-protein A from Staphylococcus aureus. Scand J Immunol. 1981;14(4):409-20.

25. Saha K, Bender F, Gizeli E. Comparative study of IgG binding to proteins $\mathrm{G}$ and $\mathrm{A}$ : nonequilibrium kinetic and binding constant determination with the acoustic waveguide device. Anal Chem. 2003;75(4):835-42.

\section{ППР дослідження формування проміжного шару біоселективного елемента імуносенсора на основі рекомбінантного білка A $S$. aureus}

О. Е. Рачков, А. О. Бахмачук, О. Б. Горбатюк, М. Й. Мацишин, Р. В. Христосенко, Ю. В. Ушенін, О. П. Солдаткін

Мета. Дослідити формування проміжного шару біоселективного елемента імуносенсора на основі рекомбінантного білка A Staphylococcus aureus із залишком цистеїну (SPACys) та його взаємодії з імуноглобуліном людини за допомогою спектрометра ППР «Плазмон». Методи. Активність використаних імунокомпонентів була перевірена за допомогою імуноферментного аналізу. Для вивчення іммобілізації білків на золотій сенсорній поверхні і взаємодій між іммобілізованим SPA-Суs і імуноглобуліном людини застосували спектрометрію поверхневого плазмонного резонансу. Результати. Продемонстрована пряма залежність сенсорного відгуку від концентрації SPA-Cys в діапазоні від 0,2 до 2 мкМ під час його іммобілізації. За допомогою білків молока вдалося ефективно знизити рівень неспецифічної адсорбції на сенсорній поверхні. Була показана пряма залежність сенсорного відгуку від концентрації IgG і поверхневої густини іммобілізованого SPA-Cys. Апроксимація експериментальних даних графіком ізотерми Ленгмюра дає значення $K_{\mathrm{d}}$ для взаємодії іммобілізованого SPA-Cys із $\operatorname{IgG} 8,5 \pm 0,7 \times 10^{-8} \mathrm{M}$ $\left(K_{\mathrm{a}}=1.2 \pm 0.1 \times 10^{7} \mathrm{M}^{-1}\right)$. Отримана величина рівноважної константи зв'язування вказує на досить сильну взаємодію, $\mathrm{i}$ ii значення узгоджується 3 літературними даними. Висно- вки. Успішна іммобілізації SPA-Суs на золотій поверхні спектрометра ППР при збереженні його високої IgG-зв'язувальної активності, селективності та стабільності сенсорного відгуку підтверджує ефективність SPA-Cуs як проміжного компонента для створення біоселективного елемента імуносенсора.

К л юч о в і с л о в а: імуноглобулін, рекомбінантний білок А S. aureus, поверхневий плазмонний резонанс, іммобілізація білка, імуносенсор, рівноважна константа зв'язування.

ППР исследования формирования промежуточного слоя биоселективного элемента иммуносенсора на основе рекомбинантного белка A $S$. aureus

А. Э. Рачков, А. О. Бахмачук, О. Б. Горбатюк, М. И. Мацишин, Р. В. Христосенко, Ю. В. Ушенин, А. П. Солдаткин

Цель. Исследовать формирование промежуточного слоя биоселективного элемента иммуносенсора на основе рекомбинантного белка A Staphylococcus aureus с остатком цистеина (SPA-Cys) и его взаимодействие с иммуноглобулином человека с помощью спектрометра ППР «Плазмон». Методы. Активность использованных иммунокомпонентов была проверена с помощью иммуноферментного анализа. Для изучения иммобилизации белков на золотой сенсорной поверхности и взаимодействий между иммобилизованным SPA-Cуs и человеческим иммуноглобулином применили спектрометрию поверхностного плазмонного резонанса. Результаты. Продемонстрирована прямая зависимость сенсорного отклика от концентрации SPA-Cys в диапазоне от 0,2 до 2 мкМ при его иммобилизации. С помощью белков молока удалось эффективно снизить уровень неспецифической адсорбции на сенсорной поверхности. Была показана прямая зависимость сенсорного отклика от концентрации IgG и поверхностной плотности иммобилизованного SPA-Cys. Аппроксимация экспериментальных данных графиком изотермы Ленгмюра дает значение $K_{\mathrm{d}}$ для взаимодействия иммобилизованного SPACys c IgG 8,5 $\pm 0,7 \times 10^{-8} \mathrm{M}\left(K_{\mathrm{a}}=1.2 \pm 0.1 \times 10^{7} \mathrm{M}^{-1}\right)$. Полученная величина равновесной константы связывания указывает на достаточно сильное взаимодействие, и ее значение согласуется с литературными данными. Выводы. Успешная иммобилизация SPA-Cys на золотой поверхности спектрометра ППР при сохранении его высокой IgG-связывающей активности, селективности и стабильности сенсорного отклика подтверждает эффективность SPA-Cys в качестве промежуточного компонента для создания биоселективного элемента иммуносенсора.

Кл юче в ы е с л о в а: иммуноглобулин, рекомбинантный белок A S. aureus, поверхностный плазмонный резонанс, иммобилизация белка, иммуносенсор, равновесная константа связывания.

Received 07.06.2015 